\title{
Association of Breast Cancer with Epstein- Bar Virus and Cytomegalovirus Infection
}

Abdulghani Mohamed Alsamarai, Aalborg Academy College of Medicine [AACOM], Denmark. Tikrit University College of Medicine, [TUCOM], Tikrit, Iraq.

Email: abdulghani.Mohamed@tu.edu.iq, galsamarrai@yahoo.com; Mobile: +9647701831295, ORCID: http://orcid.org/0000-0002-7872-6691

Sheylan Salah Abdulla, Salahuldean University College of Science [SUCOS], Erbil, Iraq.

Email: sheylan.salah@epu.edu.iq; sheylan2000@yahoo.com

Mobile: +9647504244479

ORCID: http://orcid.org/0000-0001-8584-1391

Maha Ahmed Alobaidi, Kirkuk Health Authority, Kirkuk, Iraq

Email: maha.jasim80@gmail.com

Mobile: +9647709751959

ORCID: http://orcid.org/0000-0002-0693-3878

Correspondence author: Abdulghani Mohamed Alsamarai, Aalborg Academy College of Medicine [AACOM], Denmark. Tikrit University College of Medicine, [TUCOM], Tikrit, Iraq. Email: abdulghani.Mohamed@tu.edu.iq, galsamarrai@yahoo.com; Mobile: +9647701831295, ORCID: http://orcid.org/0000-0002-7872-6691 Received: 6/11/2019 Accepted: 9/3/2020 Published: $1^{\text {st }}$ May, 2020

\section{Abstract}

Cancer is one of the most important health problems of the current era and also a leading cause of death among populations. Breast cancer is the most commonly diagnosed malignancy in women around the world, especially in the Western countries. It accounts for almost one fifth of deaths caused by cancer. In Iraq it has been detected that the number of breast cancer cases are steadily rising since the 1991 war according to the Ministry of health/Iraqi cancer registry of 2014 . Breast cancer was most frequent cancer among women and accounts for approximately one-third of the registered female cancers, with sharp increase in incidence of this tumor in young age group. The 2018 cancer registry confirmed the increase in cancer incidence including 
breast cancer. In Arab countries including Iraq, breast cancer presented in earlier age than in Western countries. Thus early diagnosis of breast cancer may influence outcomes of treatment. In a recent study in Iraq, age of breast cancer diagnosis is two decades earlier than in Western countries. In conclusion, CMV and EBV infections may play a role in breast cancer development as they have ability for induction of latent infection. This latency phenomenon attribute to continuous exposure of host cells to viral particles in low steady-state and subsequent cell transformation.

Keywords: Breast cancer, Cytomegalovirus, Epstein-Barr virus, CMV IgG, EBV VCA, EBV ENBA-1, Heterophile antibody.

Cancer is one of the most important health problems of the current era and also a leading cause of death among populations. Cancer defined as a type of disorders or disease in which uncontrolled cells division is the main characteristics and spread of these abnormal cells, either by direct growth into adjacent tissues through invasion, or by implantation into distant sites by metastasis (where cancer cells are transported through the bloodstream or lymphatic system) [1]. The uncontrolled cells division attributed to a formation of masses or lump in all cancer types. Breast cancer begins in breast tissue, which is made up of glands for milk production, called lobules, and the ducts that connect lobules to the nipple. The remainder of the breast is made up of fatty, connective, and lymphatic tissue [2].

Breast cancer is the most commonly diagnosed malignancy in women around the world, especially in the Western countries. It accounts for almost one fifth of deaths caused by cancer [3,4]. Every year, one million new cases are reported worldwide, representing $18 \%$ of the total number of cancer in women [4,5].

In Iraq it has been detected that the number of breast cancer cases are steadily rising since the 1991 war [6,7] according to the Ministry of health/Iraqi cancer registry of 2014 [8], breast cancer was most frequent cancer among women and accounts for approximately onethird of the registered female cancers, with sharp increase in incidence of this tumor in young age group. The 2018 cancer registry confirmed the increase in cancer incidence including breast cancer [9]. In Arab countries including Iraq, breast cancer presented in earlier age than in Western countries. Thus early diagnosis of breast cancer may influence 
outcomes of treatment [10]. In a recent study in Iraq, age of breast cancer diagnosis is two decades earlier than in Western countries [11].

Breast cancer usually affects tissues involved in milk production (Ductal and lobular tissues) [12,13]. It's originated from the terminal ducto-lobular unit of breast tissue. Breast cancer that has not invaded the basement membrane and thus confined within the terminal ductolobular units is termed carcinoma in-situ. Mainly, there are two types of in-situ cancers; lobular carcinoma in-situ and ductal carcinoma in-situ [14]. However, others rare forms of breast cancer were reported which include adenoid cystic, papillary and medullary carcinoma [15]. Breast cancer is generally presented with lump in breast, nipple change or discharge and skin contour change [16]. The development of breast cancer involves a progression through series of intermediate processes, starting with ductal hyper proliferation, followed by subsequent evolution to carcinoma in situ, invasive carcinoma, and finally into metastatic disease [17].

As in the case of most of the cancers, staging of breast cancer takes into consideration the size of the tumor (T), the number and location of metastatic lymph nodes $(\mathrm{N})$, and distant organ metastasis (M) [18]. Previous studies have indicated that detection of circulating tumor cells (CTCs) in the peripheral blood can be used in staging and prognosis stratification for breast patients [19,20].

Similar to other human cancer, breast cancer arises from a multifactorial process, but no specific etiological factor has been documented, there for, different breast cancer-associated risk factors have been suggested by epidemiological studies [10, 21, 22] and the genetics of the disease is now provoking speculation regarding possible hereditary influences on breast cancer risks that are related to racial or ethnic ancestry [23].

These risk factors include increasing age; mutation in breast cancer risk genes (including BRCA1, BRACA2 and p53) [10, 23,24]. Recent study [10] in Iraq indicated a significant association of breast cancer with BRC1 and BRC2 using AUC. Additionally, the mean serum BRC1 was significantly lower in women with breast cancer of $\geq$ 35 years as compared to those with less than 35 years age. Other risk factors include family history of breast cancer, late menopause, dietary habits, endogenous (estrogens and androgens), exogenous hormones (oral contraceptives, hormone replacement therapies), environmental factors (radiation, chemicals and heavy metals) [25] and certain 
pathologic findings within breast tissue, including previous breast cancer and various premalignant lesions [26].

Recent study indicated that $43.2 \%$ of women with breast cancer were of moderate socio-economic status, $68.9 \%$ were unemployed house wives, $85.1 \%$ from urban area, $64.9 \%$ were married, $36.5 \%$ were with primary school education level, $67.6 \%$ with no family history of breast cancer, $44.6 \%$ starting menarche at 13 years old, $8.1 \%$ with menopause, $48.6 \%$ no history of pregnancy, $16.2 \%$ with $6-11$ child, $21.6 \%$ nulliparous, and $28.4 \%$ with history of abortion [11].

Several reproductive risk factors including age at menarche, age at marriage, age at first childbirth, null parity, breast feeding and age at menopause are major risk factors which are mainly responsible for the variation in breast cancer incidence seen in different regions of the world [21,27].

Age plays a crucial role in breast cancer risk, with increasing age the incidence of breast cancer also increases [9]. However, studies in Arab countries indicating a shift in breast cancer incidence toward younger age groups [11]. In a study in Iraq, the breast cancer incidence was $20.3 \%$ in women with age of $\leq 20$ years, $32.4 \%$ in those with age of 21-30 years, $27 \%$ in women with age of $31-40$ years, $18.9 \%$ in women with age of $41-50$ years and $1.4 \%$ in those with age of 50 years and above. Unfortunately, $52.7 \%$ of cases are in the age $\leq 30$ years and $79.7 \%$ of cases are in the age of $\leq 40$ years. [11].

The age specific incidence of breast cancer increases abruptly with age until menopause [28]. Alwan reported a trend for breast carcinoma to affect younger age group [29]. In Iraqi population there is a significant influence of age on CEA, CA 27-29, P 53, ER and PR. However, the age not influenced the serum values of CA 15-3.

Unfortunately, most cancers do not produce any symptoms until the tumors are either too large to be removed surgically or cancerous cells have already spread to tissues, i.e, metastasis has taken place [30]. Cancer detection in its early stage is with vital importance as may influence the treatment outcomes and prognosis. Thus health education programs for women training for self examination of the breast are very important tool for early diagnosis of the tumor. However, simultaneous determination of CEA, CA 27-29 and CA 15-3 may be with predictive value for early diagnosis of breast cancer [10].

Tumor markers are used for population screening, diagnosis, staging and prognosis of breast cancer. They can also predict the 
response to therapy, monitor treatment, detect the presence of occult metastasis and monitor the course of the disease [31]. Tumor Markers are biochemical substances elaborated by tumor cells either due to the cause or effect of malignant process. A tumor marker produced by the tumor and, when present in significant amounts, indicates the presence of a cancer. They may be present as intracellular substances in tissues or may be released into the circulation and appear in serum [32].

Several serum tumor markers (STM) have been proposed to indicate the presence and future behavior of breast cancer (BC), such as carcinoma antigen15.3(CA15.3), carcinoma antigen (CA27-29) and carcinoembryonic antigen (CEA) are the most widely investigated tumor markers in women with breast cancer [33,34]. Other biomarkers emerged for prognosis and prediction of breast cancer [35] these include estrogen receptor, progesterone receptor, p53 and others [36,37]. Recent study in Kirkuk, Iraq, indicated that serum mean value of CA 15-3, CA 27-29, and CEA were significantly higher in women with breast cancer than in controls [10]. Odd ratio and relative risk confirm the association between serum increase of the three markers and breast cancer [10]. Area under curve (AUC) of ROC indicated the high sensitivity of their determination in breast cancer. Additionally, serum mean value of prolactin, progesterone receptor, estrogen receptor, glucose, $\mathrm{HbA} 1 \mathrm{C}$ and calcium were significantly higher in women with breast cancer than in controls [38]. However, circulating estrogen, progesterone, IGF-1, parathyroid hormone, and vitamin D mean values were significantly higher in controls as compared to that in women with breast cancer [38].

Viral factors are the most important class of the infectious agents associated with human cancers [39]. It was estimated that $17-20 \%$ of worldwide incidence of cancers attributable to a viral etiology [40]. Recently, viral infection implicated to play a role in breast cancer development [41]. Among viruses Herpesviridae family has been implicated as a cause of breast cancer [42]. Human cytomegalovirus [HCMV] and Epstein -Barr virus [EBV] could potentially involved in breast cancer [43-47]. HCMV women infection in Arab countries including Iraq was with a range of $77.8 \%$ to $95.7 \%$ [48-51].

In vitro studies suggest oncogenic transforming potential of HCMV [52-54]. In addition, HCMV antigens and DNA were detected in breast cancer tissue and / or elevation of serum HCMV antibodies in 
women that was precede the development of breast cancer or higher in women with breast cancer than in controls [46, 55-58].

Cox et al [46] found that increase in serum CMV IgG levels precede the development of breast cancer in some women. In addition, Alibek et al [42] suggested that the most relevant non-self antigen in breast cancer patients was HCMV as demonstrated using IgG allotypes analysis which are associated with certain tumor antigens. Certain allotype presence with HCMV seropositivity may act synergistically to lead to development of breast cancer [59]. Other studies not detected CMV in breast cancer tissue using RT-PCR $[44,60]$. Study performed in Erbil, Iraq, indicated that $77.7 \%$ of women with breast cancer were seropositive to CMV IgG and OR and AUC ROC confirmed an association between CMV infection and breast cancer [43]. In addition, HCMV DNA was detected in $20 \%$ of breast tumor specimens using Real-Time PCR [43]. Other studies reported a very wide range $(8.3 \%$ 97\%) for the detection of CMV DNA in breast cancer tissue [47, 55,6163]. In contrast, other studies not detected CMV particles in breast cancer biopsies $[44,57,60]$.

HCMV may induce breast cancer through multiple mechanisms, which include, escape of tumor cells from exposure to immune system through HCMV ability to induce immunosupression $[64,65]$. In addition, affection of cell cycle regulation, inhibition of apoptosis, activation of angiogenesis and cause increased mutation rate through HCMV gene products [64]. Furthermore, virus encoded interleukins [IL] suggested to play a role such as HCMV expression of viral analogue of human IL-10 [66]. HCMV infection induce immunosupression and this attribute to development of abnormal cells, either directly by initiation of transformation or indirectly through coinfections with other microbes [ 57,67,68]

The predominant source of HCMV transmission in human is the breast milk [55], and in women seropositive HCMV, more than $90 \%$ of their breast milk were positive for HCMV [69, 70]. Although HCMV detected in normal breast tissue [71], the prevalence of HCMV antigens was relatively higher in neoplastic epithelium of patients with breast cancer [47]. Taher et. al. [58] suggest that the role of HCMV in the pathogenesis of breast cancer is unclear. In Iraq, the detection rate of CMV IgG antibody was 100\% [72] and CMV DNA in 23.7\% of breast cancer tissue [61]. Alsamarai et al [43] found that mean serum of CMV IgG was significantly higher in women with breast cancer (1.4384 
$\mathrm{IU} / \mathrm{ml})$ as compared to controls $(1.125 \mathrm{IU} / \mathrm{ml})$ and $77.7 \%$ frequency of positivity in cancer patients.CMV infection may has an association with the development of breast cancer as the virus induce latent infection which mean a continuous exposure of the host cell to the effect of virus.

Richardson et al [56] conclude that CMV is a risk factor for breast cancer as they found a high CMV IgG antibody in breast cancer group as compared to controls. Richardson et al [57] reported in their study and meta-analysis that $96 \%$ of serum samples were positive for EBV IgG and $70 \%$ positive for CMV IgG, EBV and CMV were detected in $34 \%$ and $0 \%$ in breast tumor respectively. On the basis of their study findings and the meta-analysis suggest that limitation of molecular analysis may lead to variability in different study's findings, "hit and run" as HCMV and Epstein -Barr virus [EBV] may influence the inconsistent results, one or both viruses has a role at a later stage in breast cancer development, multiple viral infection may increases breast cancer risk, or neither virus has a role [57].

EBV in 1995 was detected in $21 \%$ of breast cancer samples [73] and was followed by a series of studies that detected EBV infection in women breast cancer [73-88]. Mazouni et al [89] detected EBV DNA in $33.2 \%$ of breast cancer tissue in France, while Aguayo et al [90] detected EBV in $6.5 \%$ of breast cancer in Chile. Huo et al [91] in a meta-analysis found that $29.32 \%$ of women with breast carcinoma were infected with EBV, with more prevalence in Asia (35.25\%) and lowest in USA (18.27\%) and conclude that EBV infection is associated with breast carcinoma. Zekri et al [92] found that EBV was detected in $45 \%$ and $28 \%$ of Egyptian and Iraqi women respectively who are with breast cancer. One study in Iraq reported a detection rate of EBV of $40 \%$ in breast cancer tissue [93]. Although, the reported studies concerning the association between EBV infection and breast carcinoma statistically varied widely, two studies reported that EBV seropositivity and IgG mean serum value were not significantly different between breast cancer and control group [46,56]. However, the role of EBV in development of breast cancer should not be excluded.

Our study [43] indicated that EBV VCA IgG mean serum level was significantly higher in women with breast cancer $(1.2672 \mathrm{IU} / \mathrm{ml})$ as compared to controls $(0.759 \mathrm{IU} / \mathrm{ml})$. In addition, EBV EBNA-1 IgG mean serum value was significantly higher in women with breast cancer $(1.492 \mathrm{IU} / \mathrm{ml})$ than in controls $(1.131 \mathrm{IU} / \mathrm{ml})$. Also, the 
frequency of positivity to EBV VCA IgG and EBC EBNA-1 IgG were significantly lower in controls $(2.1 \%, 0 \%$ respectively) than in women with breast cancer $(73.6 \%, 85.1 \%$ respectively). All women with breast cancer were positive for heterophile antibodies. Role of EBV in the development of breast cancer may differ geographically and tumor grade, size and histology were significantly correlated with EBV EBNA-1 antibody [94]. Other study found that EBV EBNA-1 antibody was significantly lower in women with benign breast tumor than in those with breast cancer [95]. Study in China suggests a significant association between EBV VCA IgA antibody and breast cancer [96].

In conclusion, $\mathrm{CMV}$ and EBV infections may play a role in breast cancer development as they have ability for induction of latent infection. This latency phenomenon attribute to continuous exposure of host cells to viral particles in low steady-state and subsequent cell transformation.

\section{References}

1. Abeloff MD, Wolff AC, Weber BL, et al. Cancer of the Breast. In: Abeloff MD, Armitage JO, Lichter AS, et al, eds. Clinical Oncology. 4th ed. Philadelphia, Pa: Elsevier 2008; pp1875- 1943.

2. Spear SL, Willey SC, Roob LG, Hammond DC, Nahabedian MY. Surgery of the breast principles and art. 2th edition. Lippincott Williams\&Wilkins 2006; pp 9-15.

3. Winer EP, Morrow M, Osborne CK, Harris JR. Cancer of the breast In: Cancer Principles and Practice of Oncology 2001; 1264-1333.

4. Bray FR, Masuyer JS, Ferlay, E F. Global estimates of cancer prevalence for 27 sites in the adult population in 2008. Int. J. Cancer 2012; 132: 1133-1145.

5. Ferlay J, Shin H, Bray F, Forman D, Mathers C, Parkin D. Cancer incidence and mortality worldwide. In: IARC Cancer Base 2010; No. 10 (version 2.0).

6. Jaffer SG. Cytogenetic study of breast cancer in Iraq. M.S.c thesis. College of Science, Baghdad University; 1999.

7. Jasim SL. Genetic polymorphism of breast tumor using polymerase chain reaction based techniques. Ph.D. thesis. College of Science, Baghdad University; 1999.

8. Iraqi Cancer Registry Center Publications. Ministry of Health. Iraqi Cancer Board, Baghdad, Iraq; 2014 .

9. Iraqi Cancer Registry, Ministry of Health, Iraqi Cancer Board, 2018. 
10. Alobaidi AHA, Jalaly A, Alsamarai AM. Biomarkers in women with breast cancer: I:CEA, CA 15.3, CA 27-29, BRCA1, and BRCA2 predictive value. Int $J$ Scint Res Sci Eng Tech 2015;1(4):342-349.

11. Alsamarai AGM, Abdulla SS. Breast cancer frequency rate shift toward younger age in Iraq. Int $J$ Scint Res Sci Eng Tech 2015;1(5):407-414.

12. Madhavan M, Priya S, Elizabeth A, Iqbal A, Vijayalekshmi N R, Prabha B. Down regulation of endothelial adhesion molecules in node positive breast cancer: possible failure of host defence mechanism. Patho. Onco. Res 2002 ;( 8):125-128.

13. Parkin DM, Bray F, Ferlay J, Pisani P. Global cancer statistics, 2002. CA Cancer J Clin 2005; (55) 74-108.

14. Atalay M C. Multidrug resistance in locally advancing breast cancer. The graduate school of natural and applied science of the middlr east technical university; 2004.

15. Winer EP, Morrow M, Osborne CK, Harris JR. Cancer of the breast. In: Cancer: Principles and Practice of Oncology. eds. De Vita Jr VT, Hellman S, Rosenberg SA. Philadelphia: Lippincott Williams \& Wilkins; 2001:1264-1333.

16. Kumar R, Kumar A, Srivastava A. Breast cancer tumor markers. Journal of Solid Tumors, February 2012; 2(1):43-46.

17. Polyak K. -Breast cancer: origins and evolution,\| Journal of Clinical Investigation 2007; 117(11)3155-3163.

18. Greene FL, Page DL, leming FI. American Joint Committee on Cancer (AJCC) cancer staging manual. New York: Springer-Verlag 2002; 6th edition.

19. Allen JE, El-Deiry WS. Circulating Tumor Cells and Colorectal Cancer. Curr Colorectal Cancer Rep 2010; 6:212-220.

20. Wulfing P , Borchard J , Buerger H , Heidl S, Zänker KS, Kiesel L, Brandt B. HER2-positive circulating tumor cells indicate poor clinical outcome in stage I to III breast cancer patients. Clin Cancer Res 2006; 12:1715-1720.

21. Davies EL. Breast cancer. Medicine 2012; 40: 5-9.

22. Abdulrahman GO, Rahman GA. Epidemiology of breast cancer in Europe and Africa. J. Cancer Epidemiol 2012:915610.

23. Jacqueline L. The Gale encyclopedia of cancer: a guide to cancer and its treatments 2005; 1:165. 
24. Dickson R, Russo J. Biochemical control of breast development. Diseases of the breast, PA: Lippincott Williams \& Wilkins, Philadelphia, ed2nd 2000:15-31.

25. Friedenreich CM. Review of anthropometric factors and breast cancer risk. Am J Epidemiol 2001; 146: 932-8.

26. Frykberg ER, Bland KI: Management of in situ and minimally invasive breast carcinoma. World J Surg 1994; 18:45-57.

27. Meshram II, Hiwarkar PA, Kulkarni PN. Reproductive risk factors for breast cancer, a case control study. Online J. Health Allied Scs 2009; 8(3): 5 .

28. Ebrahimi M, Ahdaninia M, Montazeri M. Risk factors for breast cancer in Iran: a case control study. Breast cancer research 2002; 4 (5): R10.

29. Alwan NA . Breast cancer: demographic characteristics and clinicopathological presentation of patients in Iraq. East Mediterr Health J 2010;16: 1159-64.

30. Sandhya M, Sharma P. Studies of Biochemical parameters in breast cancer with and without metastasis. Ind. J. Clin. Biochem 2004;19(4) : $71-75$.

31. Agrawal AK, Jelen M, Rudnicki J, Grzebieniak Z, Zyoeko D, Kielan W , Sonina W, Marek G. The importance of preoperative elevated serum levels of CEA and CA15-3 in patients with breast cancer in predicting its histological type. folia histochemicaet cytobiologica 2010; 48(1): 26-29.

32. Lumachi F, Stefano MM, Alba AB, Duilio P, Mario E. Relationship between Tumor Markers CEA and CA 15-3, TNM Staging, Estrogen Receptor Rate and MIB-1 Index in Patients with pT1-2 Breast Cancer. ANTICANCER RESEARCH 2004; 24: 3221-3224.

33. Yerushalmi R, Tyldesley S, Kennecke H, et al. Tumor markers in metastatic breast cancer subtypes: frequency of elevation and correlation with oucome .Annals Oncology 2011; doi: 10.1093/annonc/mdr154.

34. Li M, Kang JW, Sukumar S, Dasari RR, Barman I. Multiplexed detection of serological cancer markers with plasmon-enhanced Raman spectroimmunoassay. Chem Sci 2015; DOI: $10.1039 / \mathrm{c} 5 \mathrm{sc} 01054 \mathrm{c}$.

35. Hirata PK, Oda JM, Guembaroviski RL, et al. Molecular markers for breast cancer: prediction on tumor behavior. Disease Marker 
2014; Volume 2014, Article ID 513158, 12 pages http://dx.doi.org/10.1155/2014/513158.

36. Weigel MT, Dowsett M. Current and emerging biomarkers in breast cancer: prognosis and prediction. Endocrine Related Cancer 2010; 17: R245-R262.

37. Pultz BA, Luz FAC, Faria PR, Oliveira APL, Araújo RA, Silva MBB. Far Beyond the Usual Biomarkers in Breast Cancer: A Review. J Cancer 2014; 5(7): 559-571. Doi: 10.7150/jca.8925.

38. Alobaidi AH, Jalaly A, Alsamarai AGM, Sarhan HH. Biomarkers in women with breast cancer:II: Hormones, calcium, vit D, glucose, and IGF predictive value. World J Pharmacy Pharmacet Sci 2015;4(7):74-100.

39. Clifford GM, Smith S, Aguado T, Franceschi S.Comparison of HPV type distribution in high-grade cervical lesions and cervical cancer a meta-analysis. Br J Cancer 2003; 89: 10.

40. Vokes E, Liebowitz DN: Nasopharyngeal carcinoma, 5.Lancet. 1997; 350(9084):1087-1091.

41. Alsamarai AM, Alobaidi AHA.Association of human Cytomegalovirus and Epstein-Barr virus with breast cancer. Int $\mathbf{J}$ Med Sci [Aalborg Academy J Med Sci] 2018;1(2):1-8.

42. Alibek K, Kakpenova A, Mussabekova A, Sypabekova M, Karatayeva N. Role of viruses in the development of breast cancer. Infect Agent Cancer 2013; 8:32. doi:10.1186/1750-9378-8-32

43. Alsamarai AGM, Abdulla SS, Alkhiat ZA. Role of Cytomegalovirus and Epstein-Barr virus in breast cancer. World $\mathrm{J}$ Pharmacy Pharmace Sci 2015;4(11):115-142.

44. Antonsson A, Bialasiewicz S, Rockett RJ, Jacob K, Bennett IC, Sloots TP. Exploring the prevalence of ten polyomaviruses and two herpes viruses in breast cancer. PLoS One 2012, 7:e39842. doi:10.1371/journal.pone.0039842

45. Joshi D, Quadri M, Gangane N, Joshi R, Gangane N. Association of Epstein Barr virus infection (EBV) with breast cancer in rural Indian women. PLoS One 2009; 4, 8180.

46. Cox B, Richardson A, Graham P, Gislefoss RE, Jellum E, Rollag $\mathrm{H}$. Breast cancer, cytomegalovirus and Epstein-Barr virus: a nested case-control study. Br J Cancer 2010; 102:1665-9.

47. Harkins LE, Matlaf LA, Soroceanu L, Klemm K, Britt WJ, Wang $\mathrm{W}$, et al. Detection of human cytomegalovirus in normal and 
neoplastic breast epithelium. Herpesviridae 2010; 1:8. doi: 10.1186/2042-4280-1-8.

48. Hala MM, Alsamarai AGM, Aljumaili ZKM, Alobaidi AH. Association Between Cytomegalovirus Infection and Bad Obstetric Outcomes in Women from Kirkuk . International Journal of Public Health Science (IJPHS) 2014;3:29-42.

49. Aljumaili ZK, Alsamarai AGM, Najem WS. Seroepidemiological Study of Toxoplasma, Rubella, Cytomegalovirus and Herpes Simplex in Women with Bad Obstetric History. Midl East J Intern Med 2013;6:21-33.

50. Aljumaili ZK, Alsamarai AM, Najem WS. Cytomegalovirus seroprevalence in women with bad obstetric history in Kirkuk, Iraq. J Infect Public Health 2014 Jul-Aug; 7(4):277-88.

51. Alsamarai AGM, Aljumaili ZK. Seroepidemiology of Toxoplasma, Rubella, Cytomegalovirus and Herpes Simplex virus -2 in women with bad obstetric history. Part II: Cytomegalovirus and Herpes Simplex virus infection. Our Dermatol Online 2013;4(4):536-544.

52. Geder KM, Lausch R, O’Neill F, Rapp F. Oncogenic transformation of human embryo lung cells by human cytomegalovirus. $\quad$ Science $1999 ; \quad 192: 1134-7$. doi:10.1126/science.179143.

53. Clanton DJ, Jariwalla RJ, Kress C, Rosenthal LJ. Neoplastic transformation by a cloned human cytomegalovirus DNA fragment uniquely homologous to one of the transforming regions of herpes simplex virus type 2. Proc Natl Acad Sci U S A 1983; 80:3826-30.

54. Lepiller Q, Abbas W, Kumar A, Tripathy MK, Herbein G. HCMV activates the IL-6-JAK-STAT3 axis in HepG2 cells and primary human hepatocytes. PLoS One 2013; 8:e59591. doi:10.1371/journal.pone.0059591

55. Herbein $G$ and Kumar A. The oncogenic potential of human cytomegalovirus and breast cancer. Front Oncol 2014; 4:230. doi: 10.3389/fonc. 2014.00230

56. Richardson A. Is breast cancer caused by late exposure to a common virus? Med Hypotheses 1997; 48:491-7.

57. Richardson AK, Currie MJ, Robinson BA, Morrin H, Phung Y, et al . Cytomegalovirus and Epstein-Barr virus in breast cancer. PLOS ONE 2015; 10(2): 0118989.doi:10.1371/journal.pone.0118989.

58. Taher C, de Boniface J, Mohammad AA, Religa P, Hartman J, Yaiw $\mathrm{KC}$, et al. High prevalence of human cytomegalovirus 
proteins and nucleic acids in primary breast cancer and metastatic sentinel lymph nodes. PLoS One 2013; 8:e56795. doi:10.1371/journal.pone.0056795

59. Pandy JP, Kistner-Griffin E, Iwasaki M, Bu S, Deepe R, et al. Genetic markers of immunoglobulin $\mathrm{G}$ and susceptibility to breast cancer. Hum Immunol 2012; 73:1155-1158.

60. Utrera-Barillas D, Valdez-Salazar HA, Gómez-Rangel D, Alvarado-Cabrero I, Aguilera P, Gómez-Delgado A, et al. Is human cytomegalovirus associated with breast cancer progression? Infect Agent Cancer 2013; 8:12. Doi: 10.1186/1750-9378-8-12.

61. Mohammed AH, Kadhim HS, Hussein AA. Investigation the role of human cytomegalovirus in the invasive ductal breast carcinoma using real time PCR. Int J Current Microbiol Applied Sci 2015;4:537-542.

62. Eghbali M, Ghane M, Mirinargesi M. Frequency of cytomegalovirus (CMV) in benign and malignant tumors. Int J Mol Clin Microbiol 2012;2:175-179.

63. Al-Alwany SH, Ali SM. Molecular detection of human cytomegalovirus in Iraqi patients with breast cancer. Int $\mathbf{J}$ Advan Bio Res 2013;3:454-459.

64. Dziurzynski K, Chang SM, Heimberger AB, Kalejta RF, McGregor $\mathrm{SR}$, et al . Consensus on the role of human cytomegalovirus in glioblastoma. Neuro-oncology 2012;14:246-255.

65. Loenen WA, Bruggeman CA, WiertzEJ. Immune evasion by human cytomegalovirus : lessons in immunology and cell biology. Seminars in Immunology 2001;13:41-49.

66. Hamidulla A, Changkija B, Konwar R. Role of interleukin-10 in breast cancer. Breast Cancer Research Treatment 2012;133:11-21.

67. Alsamarai AGM, Aljumaily ZK, Alobaidi AH. Co-infections Increase the Risk of Pregnancy Outcomes. Virology Immunology $\mathbf{J}$ 2018;2(11):00201. DOI: 10.23880/vij-16000201

68. Alsamarai AGM, Hassan HM, Alsalihi FG, Alobaidi AH,Aljumaili ZK. Toxoplasma gondii, rubella, cytomegalovirus ci-infection as a risk factors for abnormal pregnancy outcome. Middle East J Family Med 2014;12:15-23.

69. Asanuma H, Numazaki K, Nagata N, Hotsubo T, Horino K, Chiba S. Role of milk whey in the transmission of human cytomegalovirus infection by breast milk. Microbiol Immunol 1996; 40:201-4. 
70. Hamprecht K, Maschmann J, Vochem M, Dietz K, Speer CP, Jahn G. Epidemiology of transmission of cytomegalovirus from mother to preterm infant by breastfeeding. Lancet 2001; 357:513-8.

71. Tsai AA, Klemm K.Viral factor and breast cancer in Taiwan. J Med Virol 2005; 55:146-88.

72. Glaser SL, Hsu JL, Gulley ML: Epstein-Barr virus and breast cancer: state of the evidence for viral carcinogenesis. Cancer Epidemiol Biomarkers Prev 2004; 13:688-697.

73. Labrecque LG, Barnes DM, Fentiman IS, Griffin BE. Epstein-Barr virus in epithelial cell tumors: a breast cancer study. Cancer Res 1995;55: 39-45.

74. Fawzy S, Sallam M, Awad NM. Detection of Epstein-Barr virus in breast carcinoma in Egyptian women. Clin Biochem 2008;41: 486492.

75. Irshaid F, Jaran A, Dilmi F, Tarawneh K, Hadeth R, Al-Khatib A. Prevalence of Epstein-Barr Virus Latent Membrane Protein-1 in Jordanian Patients with Hodgkins Lymphoma and Non-hodgkins Lymphoma. Journal of Biological Sciences 2010; 10(6), 507-513.

76. Preciado MV, Chabay PA, De Matteo EN, Gonzalez P, Grinstein S, et al. Epstein-Barr virus in breast carcinoma in Argentina. Arch Pathol Lab Med 2005; 129:377-381.

77. Kalkan A, Ozdarendeli A, Bulut Y, Yekeler H, Cobanoglu B, et al. Investigation of Epstein-Barr virus DNA in formalin-fixed and paraffin embedded breast cancer tissues. Medical principles and practice : international journal of the Kuwait University, Health Science Centre 2005;14: 268-271.

78. Perrigoue JG, den Boon JA, Friedl A, Newton MA, Ahlquist P, et al. Lack of association between EBV and breast carcinoma. Cancer Epidemiol Biomarkers Prev 2005;14: 809-814.

79. Preciado MV. Lack of evidence for an association of Epstein-Barr virus infection with breast carcinoma-another point of view. Breast Cancer Res 2003;5: E6; author reply E7.

80. Grinstein S, Preciado MV, Gattuso P, Chabay PA, Warren WH, et al. Demonstration of Epstein-Barr virus in carcinomas of various sites. Cancer Res 2002;62: 4876-4878.

81. Fina F, Romain S, Ouafik L, Palmari J, Ben Ayed F, et al. Frequency and genome load of Epstein-Barr virus in 509 breast cancers from different geographical areas. Br J Cancer 2001;84: 783-790. 
82. Bonnet M, Guinebretiere JM, Kremmer E, Grunewald V, Benhamou E, et al. Detection of Epstein-Barr virus in invasive breast cancers. J Natl Cancer Inst 1999; 1: 1376-1381.

83. Subramanian C, Robertson ES. The metastatic suppressor Nm23$\mathrm{H} 1$ interacts with EBNA3C at sequences located between the glutamine-and proline-rich domains and can cooperate in activation of transcription. J Virol 2001; 76: 8702-8709.

84. Subramanian C, Knight JS, Robertson ES. The Epstein Barr nuclear antigen EBNA3C regulates transcription, cell transformation and cell migration. Front Biosci 2002; 7: d704-716.

85. Kraus RJ, Mirocha SJ, Stephany HM, Puchalski JR, Mertz JE. Identification of a novel element involved in regulation of the lytic switch BZLF1 gene promoter of Epstein-Barr virus. J Virol 2001;75: 867-877.

86. Fan H, Gulley ML. Epstein-Barr viral load measurement as a marker of EBV-related disease. Mol Diagn 2001;6: 279-289.

87. Yasui Y, Potter JD, Stanford JL, Rossing MA, Winget MD, et al. Breast cancer risk and ,„,delayed ${ }^{\text {eeee }}$ primary Epstein-Barr virus infection. Cancer Epidemiol Biomarkers Prev 2001;10: 9-16.

88. Trabelsi A, Rammeh S, Stita W, Mokni M, Mourou A, et al. Detection of Epstein-Barr virus in breast cancers with lymphoid stroma. Ann Biol Clin 2008;66: 59-62.

89. Mazouni C, Fina F, Romain S, Ouafik L, Bonnier P, Brandone JM, et al. Epstein-Barr virus as a marker of biological aggressiveness in breast cancer. Br J Cancer 2011; 104:332-7.

90. Aguayo F, Khan N, KoriyamaC, Gonzalez C, Ampuero S, et al. Human papillomavirus and Epstein-Barr virus infections in breast cancer from Chile. Infectious Agents Cancer 2011; 6:7.

91. Huo Q, Zhang N, Yang Q. Epstein-Barr virus infection and sporadic breast cancer risk: a meta-analysis. PLOS ONE 2012; 7(2):e31656. Doi:10.1371/journal.pone.0031656.

92. Zerki AN, Bahnassy AA, Mohamed WS, El-Kassem AR, ElKhalidi SJ, et al. Epstein-Barr virus and breast cancer: epidemiological and molecular study on Egyptian and Iraqi women. J Egyptian Nat Cancer Institute 2012; 24:123-131.

93. Hanna BJ, Habib MA, Al-Mousawi HA. The expression of EpsteinBarr virus in breast cancer in relation to age. Al-Kindy Col Med J 2011; 7:78-83. 
94. Murray PG, Lissauer D, Junying J, Davies G, Moore S, Bell A, et al. Reactivity with A monoclonal antibody to Epstein-Barr virus (EBV) nuclear antigen 1 defines a subset of aggressive breast cancers in the absence of the EBV genome. Cancer research. 2003 May 1; 63(9) : 2338-3.

95. Richardson AK, Cox B, McCredie MR, Dite GS, Chang JH, Gertig $\mathrm{DM}$, et al. Cytomegalovirus, Epstein-Barr virus and risk of breast cancer before age 40 years: a case-control study. Br J Cancer. 2004; 90(11):2149-52.

96. Joshi D, Buehring GC. Are viruses associated with human breast cancer? Scrutinizing the molecular evidence. Breast cancer research and treatment. 2012; 135(1):1-15. 